\title{
Can the Earth be Sacred Once Again? Christianity and Climate Change ${ }^{1}$
}

\author{
Sean McGrath, Memorial University
}

\begin{abstract}
The following paper takes Pope Francis' Encyclical on Climate Change as an opportunity to re-open the debate, begun in 1967 by Lynn White Jr., on the theological origins of the environmental crisis. I note that the Pope's critique of consumerist modernity is strong, but his lack of a genealogical account of modernity remains a weakness of the text. I argue, with White, that the technological revolution which has caused climate change would not have been possible without Christian assumptions. The original disenchantment of the world was the Abrahamic revelation which disjoined divinity and nature, and contra to appearances, the disjunction was only exacerbated by the doctrine of the incarnation. With climate change, modernity is returning to this revelation in the form of the sobering experience of the precarity of the planet. Nature is now experienced as finite once again, and it includes us. Modernity, however, cannot be disavowed any more than disenchantment can easily be forgotten. A return to the Christian roots of disenchantment might help us to remember what we have forgotten: the virtue of contemplation, which could qualify modern attitudes of control and domination, and engender a Christian experience of reverence for nature. While this is a Christian response to the climate crisis, other religious traditions will need to come to analogous forms of earth-centered ethics if we are to achieved the integrated ecological pluralism needed for the future of civilization.
\end{abstract}

Keywords: Climate change; Pope Francis; disenchantment; contemplation; reverence.

$\mathrm{F}$ live years ago, in Paris at the twenty-first Conference of the Parties of the UNFCCC (The United Nations Framework Convention on Climate Change), 175 governments of the world committed their countries to reducing global emissions to $350 \mathrm{ppm}$, which was judged necessary by a large majority of the world's climatologists to maintaining global warming to no more than two degrees above pre-industrial averages. In 2018, it was official: we have missed that target and are now hurling headlong towards some of the most dystopian climatological predictions. At the rate of current emissions, the world is expected to hit four degrees by the end of the century. Four degrees is only two degrees more than the Paris target. But think of the temperature of a living body, rather than, say, the temperature of a bath. Four degrees means fifty-degree summer days in Toronto. It means the tundra melts and releases tons of methane into the atmosphere, causing a positive feedback loop that increases global warming incalculably. It means that oceans are more acidified than they have been in 400 million years. It means that the glaciers and ice caps have melted, raising sea levels by nearly nine meters, enough to submerge land currently home to more than half a billion people worldwide. All our coast cities will be underwater. Four degrees means the transformation of what is now the agricultural belt of the world into deserts. It means a mass migration of peoples to the north and southern poles, which would certainly destabilize governments and economies everywhere, and create new and uncontrollable geopolitical conflicts. ${ }^{2}$

To get a sense of how hard this one is to solve, think of this. According to a 2015 study, to stay below two degrees, $85 \%$ of Canadian Oil reserves cannot be burned. ${ }^{3}$ I wonder if Prime Minister Justin

1. Some of this material is a re-working of writing which first appeared in my Thinking Nature: An Essay in Negative Ecology (Glasgow: Edinburgh University Press, 2019).

2. See http://climateye.org/compilation-4c-global-temperature-rise-plausible-by-2060s-or-sooner-catastrophic/.

3. Bob Weber, "Oil sands can't be burned," CTV News, January 7, 2015, https://www.ctvnews.ca/canada/85-of- 
Trudeau is considering that when he forces pipelines on communities that don't want them? Was the Hon. Seamus O'Regan thinking about that when he threatened a room of businessmen and political leaders in St. John's to support 100 new oil wells for the NL offshore by 2030 ? But why single them out? When it comes to the action required of us by the facts of climate change, most of us are climate change deniers. We refuse to walk the talk.

Enough disaster data. I am not sure it even helps. As Scrooge asked of the Ghost of Christmas Future, "Are these the shadows of the things that Will be, or are they shadows of the things that May be only?"

The spirit did not reply but pointed to the tombstone with Ebenezeer's name on it. Scrooge continued desperately.

"Men's courses will foreshadow certain ends, to which, if persevered in, they must lead. But if the courses be departed from, the ends will change. Say it is thus with what you show me!"

The Spirit was immovable as ever. ${ }^{4}$

I am going to take the silence of the spirit as a yes to Scrooge's last question. We can change the end we see, indeed we must believe that we can. Despair is a luxury we cannot afford right now. I will resurrect an old, and somewhat theologically unpopular thesis that goes back to Lynn White Junior's 1967 article in the scientific journal Nature: the thesis concerning the genetic relationship between the Judeo-Christian concept of creation and environmental degradation. ${ }^{5}$ White, a medieval historian, argued, that the ecological collapse that is now known as the Holocene Extinction (which is the way future geologists will characterize the current age of the earth), has religious roots. The industrialization of the world, the over production and consumption of modern economies, and the atomization of human beings into self-maximizing consumers, is not simply a product of evolution, an inevitability of natural history; nor is it without cultural-historical causes. Ecological collapse is rooted in a certain attitude to the non-human world, which emerged out of medieval Europe and is bound up with the religion of medieval Europe, that is, with Judaism and Christianity. This is what Pope Francis did not say in his Encyclical on Climate Change. The Pope related environmental degradation to social injustice in no uncertain terms, with a moral force that only a Pope could command. Following Benedict the Sixteenth, and John Paul the Second, he connected environmental collapse to social injustice, and pleaded, in alignment with the Social Justice teaching of modern Rome, for an alternative economics, an alternative distribution of wealth and development of natural resources that could break with the death drive of late capitalism. To sum up a lengthy and detailed document, Francis I criticized:

- the ruthless will to dominate the world, which is at the ground of our civilization;

- the exploitation of human and non-human communities in the interest of profit;

- the reductionist science which justifies and facilitates that exploitation;

- and last but not least, the neo-liberalism which politically underwrites it. ${ }^{6}$

The Pope also explicitly defended Genesis 1:28 from the White Jr. reading that would render the Abrahamic religions particular guilty of this inhuman culture. But his defence only made Christianity sound all the more guilty. In the King James version, this highly disputed passage reads:

oilsands-can-t-be-burned-if-world-to-limit-global-warming-report-1.2177568.

4. Charles Dickens, A Christmas Carol (London: Chapman \& Hall, 1843), Stave Four, "The Last of the Spirits"; https://www.gutenberg.org/files/46/46-h/46-h.htm\#link12.

5. Lynn White Jr., "The Historical Roots of our Ecological Crisis," Science 155 (1967): 1203-1207.

6. Francis I, Encyclical Letter Laudato Si': On Care for Our Common Home, 24 May 2015, Vatican Website, http://www.vatican.va/content/francesco/en/encyclicals/documents/papa-francesco_20150524_enciclica-laudatosi.html. 
And God blessed them [Adam and Eve], and God said unto them, Be fruitful, and multiply, and replenish the earth, and subdue it: and have dominion over the fish of the sea, and over the fowl of the air, and over every living thing that moveth upon the earth.

It is this very passage which White sees as the root of our ecological crisis. It was this that drove medieval technology into unprecedented advances, on the one hand to lighten the burden of human labor, on the other, to make the future better than the past. This was also the passage which early Protestant capitalists presumably thought of when they elevated the accumulation of profit above the enjoyment of wealth, as Max Weber pointed out in his classic 1905 study of modern economies: The Protestant Ethic and the Spirit of Capitalism. Francis I defends Genesis and Christianity from this guilt. But the defence requires an alternative explanation of not only ecological crisis but modernity itself, for White Jr. and Weber are endeavouring to explain these things by looking to the development of modern Christianity. Francis I offers no such alternative explanation. If Christianity and Judaism are innocent, and Genesis 1:28 has nothing to do with ecological crisis, whence, then, modernity? Why did Europeans and their descendants set upon the world in the seventeenth century with such an intensity, resolving, above all else, to subdue nature to human purposes, to make the world a place suitable to human flourishing? Environmentalists talk of capitalism as the culprit. But whence capitalism? Where did the work ethic that industrialized the modern world come from, an attitude so at odds with the ancient hedonism of the Greeks and the Romans, or with the more tradition-bound patterns of exchange in the great civilizations of Asia, China and India? And whence consumerism? What is a consumer? They are manifestly unlike their ancient counterparts, the Epicureans and Hedonists of Greece and Rome. They have a different psychology, one that seems to be closely bound up with European attitudes, particularly the Romantic aesthetic, and even more damningly for Christendom, the sense of futurity that early Christianity introduced into the ancient world. Consumers do not live for pleasure, like the ancient Epicureans and Hedonists; they live for the future. They shop not for things, but for new selves, in an infinite task of personal upgrading. ${ }^{7}$

\section{Contemplative Disenchantment}

The phrase, "the disenchantment of the world" has now become almost meaningless by overuse. We should not forget the moment when it dawned on European consciousness that something fundamental had changed. We should not forget the shock of this recognition, which was in many ways a continuation of Nietzsche's claim, "God is dead," but was also mundanely more practical a point. This was Munich, 1918, when Max Weber gave a lecture to a packed audience on "Science as a Vocation." The first thing for the budding scientist to realize, Weber said, is that reason is now an instrument to be applied to explain that which human beings in previous eras of the world experienced in terms of magic and the supernatural. Rather than the magical cosmos of meaning, full of divinities, nature has become a thing to be used, and reason the tool to manipulate it. Reason as a tool could no longer serve as the guide to the good; it no longer had a telos, and could no longer lead us in our search for wisdom. And nature understood as resource could no longer serve, as it had before, as a norm for human behaviour; it was no longer a moral order, and had nothing to tell us with respect to the questions of good, evil, meaning, and ultimate purpose. ${ }^{8}$

Weber traced the disenchantment of the world back to the seventeenth century. He did not go back far enough. Disenchantment is not the product of modernization. Rather, modernity industrialization, technology, capitalism - is the product of disenchantment. It is not because of moder-

7. See Colin Campbell, The Romantic Ethic and The Spirit of Modern Consumerism (Oxford: Blackwell Campbell, 1987).

8. See Max Weber, “Wissenschaft als Beruf,” Gesammlte Aufsaetze zur Wissenschaftslere (Tubingen, 1922), 524-555. 
nity that the world was disenchanted, it is because of the disenchantment of the world that we modernized. And this did not suddenly happen to Europeans in the seventeenth century; it was a moment prepared for by the Mosaic revelation, that is, fifteen centuries before the birth of Christ, with the conceiving of God and creation as two wholly distinct orders of being. ${ }^{9}$ The disenchanted consciousness was incubated in medieval Europe, temporality mitigated by the Hellenization of Christianity, only to break out, fully grown in the Reformation, and the subsequent revolutions, theological, political, scientific, which inaugurated modernity. God in the Hebrew Bible is manifestly not nature, he is its Creator, so transcendent of his creation that we are forbidden imagining him or even conceiving him in creaturely terms. Nature, which in other systems of belief was fused with divinity, not truly distinguished from it, either pantheistically folded into the divine, as in Stoicism or neo-Platonism, or inhabited by divinities as in animism - nature was now conceived as a thing over and against the divine, a thing that barely existed, so dependent was it on its transcendent cause. This originally theological conception of nature as creature, and its corollary, the human being as imago Dei, entrusted with dominion over it, is at the root of the ecological crisis.

I will not, on the basis of the well-developed thesis of the theological roots of environmental collapse, advocate a post-Christian ecology, a neo-pagan ecology, or with the atheist evangelists, a modernity without religion. Religion is as inextirpable from the human spirit as is laughter. Religion is not only the problem but also the solution. The ecological crisis requires us to re-examine the way we modernized, and to look back at roads not taken. Perhaps there is another way to live together with the non-human, and indeed, with the great mass of underprivileged humans, who make possible our first world comfort.

Disenchantment is the fall from a state of comforting belief; it is the experience of a spell being broken. Cinderella arrives home from the ball barefoot, missing her fine gown and sparkling shoes. The palace, the horse-drawn carriage, the prince - all were a dream. But in the fairytale, of course, Cinderella's dream comes true in the end. Real-life disenchantment is less fortunate. It is irreversible. Children discover what they do not want to know and cannot unlearn, that Santa Claus is really a show put on by their parents, the TV studios, and the shopping malls, to make the world seem more magical than it is - and Christmas is never the same. But presumably, the one who is disenchanted is not burdened by the new knowledge, but enlightened. Disenchantment is a positive thing, is it not, an unmasking of a deception, an ascent into truth from a state of naiveté? If so, why do we regard it otherwise?

Whatever we may think about the disenchantment of the world, the Anthropocene is certainly its nadir. It has been pointed out that the Anthropocene is axiologically ambiguous: it could be read as the exaltation of the human - we are so evolutionarily exceptional as to have become a geological force - or its humiliation. We are confronted with our vulnerability to hyper-objects such as the climate (or indeed the living planet itself, the only one we know capable of supporting life). We are destined to suffer the unforeseen effects of evolution. If we once thought ourselves god-like in our capacity to transcend the material conditions of our lives, we can do so no longer. Even the fantasy of a post-human uploading of the contents of the human mind is dispelled by the simple observation that someone is going to need to materially monitor the physical data-bank, which is anything put impervious to climate. Try leaving your laptop out in the rain.

Humiliation is not necessarily a bad thing. To be brought down to earth (humble, Middle English, from the Latin humus, ground) may be the best chance we have of surviving our own success. Neither is the smashing of idols necessarily the death of nature; it might be its unveiling. With the demolition of the romanticized nature of much nineteenth and twentieth century environmental writing,

9. See Marcel Gauchet, The Disenchantment of the World: A Political History of Religion, trans. Oscar Burge (Princeton: Princeton University Press, 1999). 
the fantasy of a "balanced whole" which humans have upset by their rapacious technological will to mastery, nothing is lost but an ideological fiction.

Consider the concept of the technosphere. ${ }^{10}$ The ubiquity, systematicity, and self-regulating capacities of technology on the earth today has led some geologists to coin this new term to describe it. ${ }^{11}$ Technology is no longer simply human devices which we use, it is a system of communication, of agriculture, and transportation that all life on earth, human and non-human, in one way or another depends upon. If something goes wrong with us, all the domestic animals which depend upon us will die. The biosphere is overlaid by the technosphere, colonised by it. The technosphere is a vast decentralised, multi-nodal rhizomatic parasite. And no one is in charge: the technosphere is a new form of wilderness, proliferating without plan, wherever there is a cellphone to connect to the web - that is, everywhere. It has thrown a monkey wrench into the eco-feminist critique of technology as maledominated power exploiting a female nature. In fact, male-dominated economic and technical power is losing the struggle to maintain control of the technosphere - from corporations vainly trying to control file-sharing or the unregulated exchange of goods, to the absence of any clear solutions to climate change. Technology itself has now assumed characteristics associated with the "female earth": the technological is not a tool but a "space," a receptacle, for the growth and development of organic life; it is not abstract but relational, creative of a proliferation of communities both human and non-human, as well as of new forms of social and political life. The technosphere depends on the biosphere like a parasite. And like many parasites, it is killing its host. But symbiosis can change forms: the technosphere could evolve into a commensal or even mutual symbiosis with the biosphere, which would indeed be in its own interest. One could imagine a crucial role for $\mathrm{AI}$ in this scenario, regulating the production and flow of goods and services planet-wide in such a way as to not only leave the biosphere unharmed but to improve it.

What indeed, does nature or technology mean in such an era? Developments such as the concept of the technosphere divest us of traditional ways of thinking about nature, even destroy our traditional meanings. But nature is a symbol and can survive the extinction of one or another of its meanings. A living symbol, as Tillich, Lonergan, or Ricoeur argued, is distinct from a scientific sign in that its equivocity is a strength, not a problem: the living symbol can continue to generate new meanings even when its original sense and reference have ceased to function. ${ }^{12} \mathrm{We}$ may have to wait, however, to see

10. The term "technosphere," was coined by a group of geologists in 2015. See Mark Williams, Jan Zalasiewicz, P. K. Haff, Christian Schwägerl, Anthony D. Barnosky and Erle C. Eills, "The Anthropocene Biosphere," Anthropocene Review 2, no. 3 (2015): 196-219.

11. The technosphere regulates itself through the so-called "internet of things"; it does not (yet) organize itself. Selforganization would require a great step forward in AI, the advent of so-called artificial general intelligence (AGI), a machine that can program itself and invent new machines without human input. While the feasibility of such a level of machine learning is disputed, it is worth noting that a strong contingent of AI researchers anticipate its development in this century. See Max Tegmark, Life 3.0: Being Human in the Age of Artificial Intelligence (New York, NY: Knopf, 2017). For a more skeptical account of the self-programming capacities of machines see Brian Cantwell Smith, The Promise of Artificial Intelligence: Reckoning and Judgment (Cambridge, MA: MIT Press, 2019).

12. Symbols, according to Tillich, "participate in the reality of that to which they point" (Paul Tillich, Systematic Theology, three volumes in one [Chicago: University of Chicago Press 1967], v. II, 239). Where the sign is arbitrary and replaceable, and has no intrinsic relation to what it represents, "the symbol grows and dies according to the correlation between that which is symbolized and the persons who receive it as a symbol" (Tillich, Systematic Theology, v. II, 239). Symbols (the sacraments of the church are a preeminent though not exclusive example) engage not only the mind but also the body, that is, they evoke not only thought but, above all, feeling. They "open up levels of reality, which are otherwise closed for us ... otherwise hidden and cannot be grasped in any other way" (The Essential Tillich: An Anthology of the Writings of Paul Tillich, ed. F. Forrester Church [Chicago: University of Chicago Press, 1999], 42, 47). It should be clear that "nature" in environmental discourse functions as a symbol in this Tillichian sense. As such, the death of nature proclaimed by various authors of late (Bruno Latour, Timothy Morton, Slavoj Žižek) is premature. The precision of the sign represents a constriction on the symbol, which must be free to evoke, without restriction, feeling and anticipatory meaning. But this unrestricted evocation of sense, drawing as it does upon collective memory and unconscious feeling, is not something that is achieved deliberately or by definition: it is not the sign user who decides whether a symbol lives or dies. Symbols "grow out of the individual or collective unconscious and cannot function without being accepted by the unconscious dimensions of our being" (Tillich, Essential Tillich, 42). For a similar line 
what new sense nature could have for us in the Anthropocene. This waiting is the essence of disenchantment: the old comforting associations of nature as cosmos, order, mother, are taken from us, and a new one has not yet emerged. The question of that out of which we have all been born, the common source of the remarkable power of both human and non-human life - the question of nature, in other words - is far from closed. ${ }^{13}$

The full genealogy of the term is enough to prove that disenchantment does not equal atheism, quite the contrary. It was only within the horizon of transcendence, the divine transcendence of the one Creator God of the universe, that nature could be disenchanted, de-mythologized, and divested of divine immanence. And it was not a general sense of transcendence that disenchanted the world in the modern era; it was, as Marcel Gauchet has pointed out, Christian transcendence that killed the gods of nature and flattened the hierarchies that had always ordered ancient societies. ${ }^{14}$ Contra to appearances, the doctrine of the incarnation hyperbolically intensified the Abrahamic sense for the transcendence of God. When "God" became "human" in the singular event of the birth of Christ, two things happened that transformed Mosaic monotheism. First, the Creator as such was rendered absolutely inaccessible, without phenomenality, no longer manifest in theophanies, pillars of clouds, burning bushes, sacred mountains and trees. God was now irretrievably hidden to consciousness save insofar as he is incarnate in this man Jesus, "the image of the invisible God" (Col 1:15). Second, the human was validated in both its creatureliness and exceptionalism. The human nature of Christ is not one site for the appearance of divinity among others (the desert, the wind, the temple); at least according to the Church Fathers who met at Chalcedon in 451 to define the hypostatic union, the human is the only place of divine incarnation, and it is not such because it points to its other, the divine - the human is not a symbol of God. Rather, the human has become in itself divinized. Jesus is neither a symbol of God, nor a sign of the divine, as was the burning bush that spoke to Moses. He is not a trace of the transcendent, but the transcendent itself, in bodily presence. In a single stroke, the human is untethered from a certain monolithic conception of the divine, exalted above all other creatures, and set free. This is what Gauchet calls "the law of human emancipation through divine affirmation": "the greater the gods, the freer the humans are." 15 At the same time, the human is made responsible for creation, and answerable for it. The significance of this original, theological disenchantment of the world should not be missed: transcendence was not abolished with the Hebraic disenchantment of nature; quite the contrary: it was now for the first time plain to see how beyond us, how wholly other, God truly was.

When the Creator God becomes fully present in the incarnate Christ, transcendence becomes absolute. As Luther understood, the nadir of God's absence, his hiddenness in the shame of the cross, is the precise point in space and time at which God becomes most fully present, and vice versa. Now heaven is truly sealed for us - our only point of access to divinity is the perfected human being. For Christ is not only the image of the invisible God, he is also the visible, perfected Anthropos, the new

of thought, see Paul Ricoeur, Freud and Philosophy: An Essay on Interpretation, trans. Denis Savage (New Haven: Yale University Press, 1970), 9-19, 531; Bernard Lonergan, Method in Theology (Toronto: University of Toronto Press, 1971), 64-9. For the logic of the symbol/sign distinction, see Ernst Cassirer, An Essay on Man: An Introduction to the Philosophy of Human Culture (New Haven: Yale University Press, 1944), and Susanne K. Langer, Philosophy in a New Key: A Study in the Symbolism of Reason, Rite, and Art, third edition (Cambridge, MA: Harvard University Press, 1957). 13. The symbol OOWWAAB, that "out-of-which-we-are-all-born," is Latour's. See Bruno Latour, Facing Gaia: Eight Lectures on the New Climatic Regime, trans. Cathy Porter (Cambridge: Polity Press, 2017), 159.

14. See Gauchet, Disenchantment, 47-66. This social re-ordering entails the abolition of the ancient justification of a stratification of society on the basis of a natural hierarchy extending from the lowest forms of life, through the servile classes of humans, to the rulers and priests, and upwards, without break, into divine intermediaries, culminating in the Godhead, which is continuous with the cosmos that emanates from it. If hierarchy persists in the liberal democracies founded upon the doctrine of the imago Dei inherited from Christendom, as it no doubt does, it is not because inequality is inscribed into the nature of things. There is no natural stratification for hierarchy in a randomly evolving universe, save the natural "right" of the strong to rule over the weak. And far from supporting "might makes right," liberalism contests it by introducing the concept of political equality. We might not be born equal but we can, and indeed must, be made equal.

15. Gauchet, Disenchantment, 51. 
Adam (1 Cor. 15:45), and the sign of the life that awaits us. The Christ seals the divine, but within his personality one finds a new, immanentized transcendence. Divinity is now to be achieved through the intensification, expansion, and historical development of all that is most truly human, not, as in most of the religious traditions of the ancient world, through its suppression.

At the same time that transcendence is both absolutized and rendered singularly immanent in the Christ, transcendence is temporalized. The future now opens before humanity as a blank slate of limitless possibilities. Incarnation has not been achieved once and for all but is still to come - that is Paul's original point concerning the Resurrection. The essence of the Pauline proclamation of the incarnation, crucifixion, and resurrection of the Christ is this: we are not yet complete. The past does not fully determine us, for what we will be has not yet been. Christianity is a religion of the future; resurrection is an eschatological event, it points forward, not backwards. ${ }^{16}$ Isn't this the answer to the sceptic who looks at the plainly broken world and asks the Christian what all the talk of redemption is about? What evidence is there that we are any better off morally than we were prior to Christ? If Christ redeemed the world, why do we remain mired in sin? The answer is that the resurrected Christ is not an end point but a beginning, not the full actualization of divinity in history but an eruption of the potency for justice, which Jesus called the Kingdom of God, into a situation that had become monotonously fixed in certain patterns of injustice. ${ }^{17}$ Christians do not rest upon and presuppose but move towards the perfection revealed in the resurrected Christ. Herein lies the kernel of truth in post-humanism: the longed-for perfection of the human being is ahead of us, not behind us, in some golden age. But the folly of post-humanism is the assumption that the means towards such transcendence are merely technical, and thus at our disposal. The human is the door that opens to the unlimited. The Christian revelation is the unleashing of human possibility. At Chalcedon humanity is in a sense first defined, first set apart from its genuine other, the divine. This breakthrough to history is predicated upon the closure of a certain perennial and naturalist sense of the divine, a certain recurring and universal pantheism, a perennial sense for divine immanence, which is always, at bottom, a form of determinism. There are no more gods in nature, after Easter, for what we looked for in divinity - power, glory, ultimate meaning - is present in the Christ, the new Anthropos, or not at all. "The gods lie dead where the leaves lie red, for the flame of the sun is flown. The gods like cold where the leaves lie gold and the child comes forth alone."18

For a variety of historical reasons, from the egalitarian ethics of early Christianity, to the JewishChristian sense for eschatological time - both of which were retrieved by the Reformation, which demolished the medieval hierarchical cosmos and the social stratification which reflected it Christendom modernized. ${ }^{19}$ Indeed, it is not a stretch to argue, as Collingwood, Löwith, and Gauchet have, and before them Hegel and Schelling, that Christendom produced modernity. With modernity, certain Christian values became effective in history on a global scale for the first time: equality, human dignity, even progress, none of which are typical of ancient peoples. But as Christendom modernized in a one-side and distorted form other Christian virtues were forgotten. In particular, in the mad rush to calculatedly reduce the world to that which could be controlled and domesticated, the contemplative practices of Christendom were forgotten. Contemplation, a word hardly used today, was once a regular feature of Christian thinking. Indeed, contemplation was understood throughout the Middle Ages, and all the way back to the Alexandrian school of Clement and Origin, to be foundation of the Christian life.

16. On Paul's notion of the absolute future as the fulfillment of what has occurred in the Christ event, see 1 Cor 3:18; Phil 3:13; 1 Cor 15:28. On the place of New Testament eschatology in the history of revolution, utopian thinking, and futurism, see Ernst Benz, Evolution and Christian Hope: Man's concept of the Future: From the Early Father to Teilhard de Chardin, trans. Heinz G. Frank (Garden City: Anchor Books, 1965).

17. See Jürgen Moltmann, The Trinity and the Kingdom, trans. Margaret Kohl (Minneapolis: Fortress Press, 1980), 8486.

18. G.K. Chesterton, "Child of the Snows" (1926), https://www.chesterton.org/a-child-of-the-snows/.

19. On the relation between modernity and the Reformation see Michael Allen Gillespie, The Theological Origins of Modernity (Chicago: University of Chicago Press, 2009). 
But contemplation is of course not uniquely Christian, and we have learned much from Buddhist and Hindus on contemplative practice in the last two hundred years. Contemplation is a universal spirituality expressed in all religions in various perennial practices, such as monasticism, retreat, solitary prayer, and which is maintained in secular societies above all by artists.

Contemplation is notoriously difficult to define, but I'll venture it anyway. Contemplation is not union with God. It is not mystical in that sense. It is not esoteric or all that unusual. Contemplation is the attitude of one who receives the meanings of things as they reveal themselves in themselves, even while the origin of those things remains a mystery. It is what Heidegger calls besinnliches Denken, that primordial form of thought "which contemplates the meaning which reigns in everything that is." 20 Contemplation leaves everything to its own origin. It stays with the mystery of being. The origin, which the contemplative is not too quick to name, is infinite, because unbounded by any conception we can form of it. The great contemplative Thomas Merton writes, "Contemplation is the highest expression of man's intellectual and spiritual life. It is that life itself, fully awake, fully active, fully aware that it is alive. It is spiritual wonder. It is spontaneous awe at the sacredness of life, of being. It is gratitude for life, for awareness and for being. It is a vivid realization of the fact that life and being in us proceed from an invisible, transcendent and infinitely abundant source." ${ }^{21}$ Worthy of note in Merton's description is the absence of a direct reference to a personal God. Contemplation is not the direct experience of God, not a mystical encounter with the Creator nor a personal experience of salvation (although such peak experiences may indeed occur in contemplative life). Contemplation is an experience of the facticity of being and of the contingency of earthly existence (the gift-quality of being), all of which astonishes the contemplative and leads to the terrifying but liberating realization that we depend on that which transcends us.

Isn't this sudden, but quiet, and somehow always familiar awareness of our undefined transcendent origin exactly the attitude we need to counter anthropocentric hubris? And it is not rare or mystical in anyway. It is as common as the air we breathe, as common as the micro-holidays of mindfulness we take in the course of an ordinary day: closing your eyes in the warmth of the returning sun, watching the shadows lengthen at the end of the day, stopping to talk to a cat that crosses your path. As such contemplation is the antidote to anthropocentrism, that narcissistic humanism which induces Cartesian despair, the horror that we are homeless in the universe, because all meaning appears to depend upon us and our constructs. In Thinking Nature, I propose contemplation as a modification of what I call the three principle features of modernity: critique, control, and calculation. We need not reject modernity; the neo-Romantic re-enchantment industry is not only a political dead-end, it is an ideological distortion. It is a disavowal of what we have learned about the material world in the modern era, and in the past century especially. We need, rather, to re-baptize modernity by qualifying it, leavening its industry and zeal with contemplative reverence for being. This contemplative modification could change everything, and usher in a new era of contemplative critique, contemplative control, and contemplative calculation, indeed a fundamentally new approach to science and technology. ${ }^{22}$ Contemplative critique is critique that emancipates human beings from ideology without taking the fatal misstep of arrogating to humanity power over truth.

20. Martin Heidegger, "Memorial Address," in Discourse on Thinking, trans. John M. Anderson and E. Hans Freund (New York: Harper and Row, 1966), 46. The German adjective besinnliches, related to Besinnung (reflection) and clumsily translated as "meditative," has at its root, Sinn, "sense" or "meaning." Contemplation is a special experience of meaning as unproduced or underived.

21. Thomas Merton, New Seeds of Contemplation (New York: New Directions, 1961), 1.

22. Excellent examples of contemplatively qualified science and technology include developments in regenerative design, permaculture, and ecosystems services. "Permaculture is a philosophy of working with, rather than against nature; of protracted and thoughtful observation rather than protracted and thoughtless labour; and of looking at plants and animals in all their functions, rather than treating any area as a single product system." David Holmgren and Bill Mollison, Permaculture One: A Perennial Agricultural System for Human Settlements (London: Transworld Publishers, 1978), 128. 
The contemplative knows that the subject is not the producer of meaning but the one for whom the meanings of things become manifest. There is a naked and pure objectivity to the primordial showing of meaning. Similarly, the controlling consciousness of the modern locks the human into mechanical patterns of behaviour and response. Contemplative control, by contrast, is the mindful assumption of responsibility for the development of the earth. But the earth is not ours alone; it belongs also to nonhumans and to future humans alike. It may be our vocation to develop and perfect it, but we will never possess it, and one of the lessons of the Anthropocene is that we cannot possess it, for it possesses us. Herein lies the meaning of stewardship in the Catholic interpretation of that much-maligned passage of Genesis (Gen. 1: 26): when God gives Adam “dominion," God makes him a steward, not the possessor, of the earth. A steward, Pope Francis reminds us in Laudato $\mathrm{Si}$ ', is responsible for lands and properties that are not his own possession. ${ }^{23}$ Contemplative calculation is non-totalizing calculation, means-end thinking that is not an end in itself - that is, calculation which is not absolutized, not predicated on a reductionist ontology in which all qualities are reduced to quantities. Contemplative calculation is means-end thinking for the sake of the emancipation of the human and the just development of the earth in accordance with the earth's natural patterns of growth, regeneration, and homeostasis.

\section{Finitude / Fragility / Reverence}

Climate change has reactivated a monotheistic sense for the finitude of nature, and more immediately, a sensitivity for the fragility of the biosphere, at least in terms of its capacity to feed and shelter eight billion humans. Far from being a post-Christian attitude, the sense for the finitude and fragility of nature is a return to the original Abrahamic revelation, the revelation of the precarity and gratuity of being, which was only intensified in the Christ event. Nature is creature, like us, and as such wholly dependent on the good will of God, not only for its origin, in an unfathomable act of free creation, but also for its moment to moment preservation in being. This Anthropocenic wake-up call represents a necessary correction of a certain modernist hubris. Nature was misconceived in early modernity as the other of the human, and so as endless resource for the self-maximization of a being who in essence transcended nature. This was not only an usurpation of the position of the divine, it was also a denaturalization of the human. The Abrahamic revelation knows nature, not as the other to the human, but as the other to the divine. Nature is not finite by virtue of being delimited by human freedom; in fact, it includes us as its imago Dei, its site of incarnation, or as the khalifa of Allah. In each instance, the human is regard as at once natural and exceptional, the pinnacle of creation, but no less a creature for that.

Climate change is an opportunity for rethinking what it meant from the beginning to call nature a creature, that is, a being like ourselves, one that does not bring itself into existence but for whom existence is unnecessary and accidental. The doctrine of divine creation is the original disenchantment of the world. It spelled the end of paganism, at first in the Mediterranean, and now, in every nation on the earth that has succumbed to the secularism, which is the historical effect of the monotheistic doctrine of absolute transcendence. ${ }^{24}$ Is this not one of the reasons why ecology is the new site of the sacred for so many of us? In the age of planetary precarity, we are reminded of the contingency of creation. Contingency can be interpreted as meaningless accident and lead to nihilism, of course. But it can also be interpreted in a spirit of wonder and lead to gratitude, as it has in the monotheistic traditions throughout history. ${ }^{25}$ Let us stay with this original, Abrahamic disenchantment, the revelation of the finitude and fragility of nature in the monotheistic doctrines of divine creation and preservation, and find our way from there, not to despair but to contemplative reverence for all that is. Disenchantment is not reversible. We do not have access to lost pagan attitudes, any more than the child who discovers the

23. Francis I, Laudato $\mathrm{Si}^{\prime}, 67$.

24. See Gauchet, Disenchantment, $101 \mathrm{ff}$.

25. See, for example, Psalm 19; Francis of Assisi's Canticle of the Sun; Rumi's "The Song of the Reed," from his Masnavi, for, respectively, Jewish, Christian, and Muslim expressions of wonder at the finitude and fragility of creation. 
real secret behind Santa Claus can return to the magic of the Christmas he enjoyed before he learned the truth. But the real Christmas is way more interesting anyway, and so why would he want to go back? We cannot forget the scientific and religious history of the West. And disenchantment is not at all at odds with reverence; quite the contrary.

The term "reverence" has a history in ecology. Albert Schweitzer received the 1952 Nobel Peace Prize for his concept of a universal ethic based on "reverence for all life" (Ehrfurcht vor dem Leben). On a boat trip on the Ogooué River in French Equatorial Africa in 1915, where he was travelling to set up the Albert Schweitzer Hospital, Schweitzer became obsessed with the question of what principle was sufficiently universal and secular to found a global ethic. He hit upon the phrase "reverence for all life" one evening as the barge passed by a herd of hippopotamuses at sunset. ${ }^{26} \mathrm{We}$ revere life, according to Schweitzer, because "we are life that wishes to live and are animated by a will in the midst of other lives animated by the same will." ${ }^{27}$ My use of the term "reverence" differs in two important ways from Schweitzer's: first, I do not limit reverence to life, and so I disentangle the concept from vitalism and the Schopenhauerian ethic of the will, which we know influenced Schweitzer. ${ }^{28}$ I would rather attach reverence to the gift-quality of the earth, and so extend it to water, air, minerals, molecules, et cetera. Second, I do not hesitate to argue that reverence should be accompanied by moral judgement such that we recognize among "the things that are" those things that should not be (and that we ought to destroy - for example, the Corona virus). With these two important caveats, I think a re-reading of Schweitzer is long overdue, and a retrieval of his notion of reverence is urgent. Ecological civilization depends upon a transformation in the general will, a new ethic of the earth that engages humanity on the deepest, most affective and spiritual levels of existence. ${ }^{29}$

Reverence for nature is not mechanical and cannot be imposed on people from outside; it has to come from within. ${ }^{30}$ Genuine reverence arises as a spontaneous expression of the beauty, the goodness,

26. Albert Schweitzer, Out of My Life and Thought: An Autobiography (Baltimore, MD: John Hopkins University Press, 2009), 154-5.

27. Schweitzer, cited in James Brabazon, Albert Schweitzer: A Biography, Second Edition (Syracuse: Syracuse University Press, 2000), 271.

28. David Goodin, "Schweitzer Reconsidered: The Applicability of Reverence for Life as Environmental Philosophy," Environmental Ethics 29, no. 4 (Winter 2007): 403-421.

29. On Schweitzer's philosophy in general, see David Goodin, The New Rationalism: Albert Schweitzer's Philosophy of Reverence for Life (Montreal: McGill-Queen's University Press, 2013); idem, An Agnostic in the Fellowship of Christ: The Ethical Mysticism of Albert Schweitzer (Minneapolis: Fortress Academic, 2019). Where Schweitzer sees in moral agency an "ontic" difference that does not fundamentally distinguish the human from the non-human, I see an ontological difference, an essential attribute, unique to the human, which testifies to the embodied spirituality of the human being, and which is also manifest in other curious features of homo sapiens, notably the human being's capacity for aesthetic judgment and for self-reflection. The human difference, however, is hardly grounds for cruelty or instrumentalization of the non-human - quite the contrary. One who has in fact developed their capacities for moral agency and their aesthetic, contemplative abilities (neither of which are common nor possible without a large degree of self-knowledge) will need no argument to prove to him or her that, for example (1) factory farming of animals, where the pain and suffering of creatures raised for meat is subordinated to the need for profit, is immoral, and (2) creatures such as grizzly bears should be protected because they are, if we must use the inadequate phrase, "intrinsically valuable." It is not a consciousness of the human difference that leads to animal cruelty and indifference to the biosphere; it is rather ignorance or suppression of the human difference which promotes animal cruelty and degradation of natural environments. The human being in the economic calculus that justifies animal cruelty and bio-degradation is not generally regarded as a self-conscious moral agent, but rather more typically, along utilitarian lines, as a ruthless self-maximizer. Evolution has placed us at the top of the food chain because we are better at using everything to get what we want, and we have every natural right to do - so the story goes. In opposition to this scientistic reductionism, which Schweitzer also seems to be prone to, I side with Schelling, who argues that the human being can rise above or sink below the non-human animal but is never simply equal to it. See F.W.J. Schelling, Philosophical Investigations into the Essence of Human Freedom, trans. Jeff Love and Johannes Schmidt (Albany: State University of New York Press, 2006), 40. Slavoj Žižek has, with characteristic aplomb, argued that if the human being were merely natural, it would fit in better into its environment, like a predator among predators; instead it rises up in Luciferian titanism to the point of posing a threat to the whole biosphere. See Slavoj Žižek The Indivisible Remainder: On Schelling and Related Matters (London: Verso, 1996), 63.

30. This is the heart of conservative environmentalism, which objects to the state-imposed ecology of the left (i.e., the Green New Deal) on the grounds that such massively regulated and state administered approaches will inevitably deny communities the opportunity to develop their own environmental virtues and incentives to ecological ways of living by 
and the fragility of the earth. Such an attitude cannot be taught, but requires a contemplative time and place, in which the person has the freedom to awaken the sense of wonder for existence, which is so natural in children, and so rare in adults. We must cease deluding ourselves that we are the masters of the earth and the architects of order in the universe. Contemplatives are spontaneously and genuinely reverent, and reverence induces contemplation. The reverence for nature which could found the planetary civilization to come will not be an ideology imposed on people by political authorities; it will be an interior attitude that arises spontaneously in the hearts of all those who allow themselves and are allowed by the social, economic, and political conditions of their lives, the time and place to think, sense, and feel the beauty and precarity of existence.

Contemplative reverence for nature is analogous to the attitude with which we spontaneously "respect" the humanity of the other. The Kantian tradition teaches us that to respect another person is to adopt a posture of "non-interference" in order to leave them free "to pursue ends and goals they have chosen for themselves." ${ }^{31}$ By respecting the other, I recognize in them a spontaneity and destiny that is uniquely their own, just as my path is also my own. Respect is the attitude that sees in the other one like myself. We respect other persons because we recognize in them the same freedom (or better, responsibility) that we know in ourselves. Reverence is not respect; there is a breach of continuity between the human and the nonhuman that is acknowledged in acts of reverence: We are free; they are not. To deny this is to deny that we have responsibility for reversing the mess we are in, where they do not. And yet we do not gaze at them as though they were alien to us. We see in them something that is also in us, something that we hold sacred and revere in ourselves. If we were to deny them reverence, we would in that same act deny it of that deepest part of our earthly being. Reverence for nature need not, then, be tied up with a program of re-enchantment or a spurious adoption of mysticism. Nor do we need to be instructed in it. It is rather spontaneous so long as the experiential conditions for its possibility are present.

Contemplative reverence is anything but quietist or politically neutral, any more than contemplative Christianity, as Eckhart or Cusa taught it, was quietist or apolitical. When we contemplatively revere the earth, we come to see that the degradation of the non-human is essentially connected to the degradation of human society, as Pope Francis has made powerfully clear in Laudato $S i$ '. The demise of the one is the demise of the other. Interdependence, of which all ecologists speak, should also be understood theologically: care for our fellow human beings and care for the environment are, theologically considered, the same thing, because the two are indissolubly interdependent. In Laudato Si', Pope Francis argued that we cannot talk about preserving wilderness, preserving biodiversity and reducing pollution without also talking about a more just distribution of the finite resources of our common earth. I take this to mean, that we will not have a sound ecology until we also have a sound anthropology; environmentalism needs to be grounded in an authentic humanism if it is to become a global politics. I believe that among the powerful there are very few genuine climate change deniers. Those who have defected from the Paris Accord are deniers of universalism: they do not believe that we should have to carry the burdens of others, for they do not believe in human equality. While there are poor countries upon whom they can externalize the effects of industrial activity and overconsumption, they see no need to change. Isn't this anti-universalist thinking motivating research into stratospheric particular injection (SPI): the first world will develop a heat shield over their land at the expense of the poor?

learning to better care for their own. See Roger Scruton, How to Think Seriously About Saving The Planet: The Case for an Environmental Conservatism (Oxford: Oxford University Press, 2012). The conservative argument no doubt goes too far, and what we need above all is a bi-partisan approach, but it is so baldy under-represented in the current debate that is well worth attending to, if only to balance out a lop-sided argument that is pitting urban progressives against rural conservatives.

31. Victor Seidler, Kant, Respect, and Injustice: The Limits of Liberal Moral Theory (Abington: Routledge, 1986), 19. 
Most importantly, Pope Francis affirms, against modern dualistic thinking, the solidarity of creation, the home common to all humanity and all life. Nature is not our other; we are of nature, we are thinking nature. In the face of the anthropogenic climate change we need to recognize that our common home is in peril and that the purely scientific fixes on offer are not enough. The Pope calls the mobilization of all human knowledge and practice in the service of the health of the earth community, "integral ecology": all academic disciplines, all human endeavours, from palaeontology to poetry, from sociology to spirituality, are needed now for the sake of collaboratively producing a program of care for our common home. He carefully frames his remarks in terms of concentric circles of diverse audiences: all Catholics, all Christians, all monotheists, all human beings.

For a Christian, at least, the point must be this. What we contemplatively revere is the nature that is given to us to better steward in the Anthropocene, Anthropocenic nature: nature as creature, not Creator, immanent, not transcendent, as contingent and dependent as we are, full of beauty and ugliness, good and evil, in part organic, in part artificial, in part habitable, in part uninhabitable, in part alive, in part non-living, and everywhere in need of us, as much as we are in need of it. Nature is gift, and as gift, has a fearsome contingency about it. No gift need be given; the gift that must be given is no gift. To be gifted is to be the contingent recipient of a contingency. To use an excellent theological term, it is to be graced. Both Lynn White Junior and Pope Francis end their environmental manifestos with an invocation of St. Francis of Assisi. In his Canticle to the Sun, St. Francis speaks of how nature reminds us of God in its glory and beauty, but it is not God. It is of the same substance as us: it is sister and brother. As such, it deserves better than we have offered it of late. For a Christian to revere the earth in the Anthropocene is to acknowledge, in a new way, its sacredness. But no sense of the sacred is possible in the absence of a living practice of transcendence. Sacredness is the very feeling of transcendence, it is the phenomenality of the transcendent. I feel the sacredness of a gift because I recognize how the freedom out of which it was given transcends the order of necessity that otherwise governs human relations. The gift is horizoned by the unfathomable freedom of the other, it has a beyond quality. So too does the earth.

Along such lines, I believe, a Christian - Catholic, Protestant, Orthodox, or secular - should think about the issue of climate change. In the end, only a shared theological insight will unite Christians to make the changes that are needed: a sober recognition of our common origin, a down-to-earth and universal acknowledgement that these material conditions, air, land, water, are the very limits of life itself and so should not be commodified: they are neither possessions nor rights, since without them one cannot possess or claim a right at all. They are beyond the relations that rule all other interactions on earth. We revere the earth because it is the very gift of life itself. And it makes us one. We revere it, then, also because its ultimate gift is not only life under any circumstances, but sustainable life, life at peace with itself. We revere the life-giver and the peacemaker. I don't think Jesus would mind if we added to the Beatitudes, for in the Anthropocene we have come to recognize that peace is not an option, but a necessity, and that it will not be produced by a merely human collective, it will be given by the earth, which gives us everything. Blessed is the earth, the peacemaker, revere her, for without her, you shall perish, and with her, all things are possible. Blessed is the earth, the peacemaker, for it shall be called child of God.

Other traditions, religious and non-religious, may come to the same conclusion via different premises. An integrated, global response will need to be pluralistic, for the ecological crisis facing the word requires a degree of collaboration and an integration of theory and practice never before seen in human history. If it is to happen, it will not come about through the universal adoption of a single unified theory of ecology and economy, nor through a single religious attitude. We don't have time to defeat capitalism or sort out the differences between the two most populous claimants to the inheritance of Abrahamic faith (Christianity and Islam). Rather, the great diversity of economies, religions, and philosophies that drive human behaviour will need to be united in response to a common threat. The analogy often used is the mobilization of diverse societies in times of war. Rich and poor, socialist and 
capitalist, Democrat and Republican, atheist and believer, overcame their differences in the United States in the early 1940s to defeat what they regarded as their common enemy, fascism in Europe and the South Pacific. Something like this unification of otherwise opposed peoples will need to happen in the years to come if we are to create the conditions for the new, ecological civilization, to succeed our current Holocene civilization - granted on a scale that is quite unprecedented in human history. ${ }^{32}$ What I have done in this essay is sketch the outlines of a broadly Christian response to climate change on the assumption that it will not be, and cannot be, everyone's response. We will not agree on the means, but we must agree on the end. The destruction of the other's habitat must be recognized as also our loss: what Timothy Morton calls "the ecological thought," interdependence must come to replace our outdated neo-Darwinian assumptions of competition. ${ }^{33}$ Only thus will the recognition dawn on all of us that, however diverse we may be in ethnic origin, religion, economic class, political view, or even species, what we share in common - this delicate, singular garden called planet earth - is more important than what divides us. I have written from a Christian perspective in this essay, but I believe that similar thoughts can be found in non-Christian authors. One finds such arguments among contemporary Muslim thinkers, ${ }^{34}$ Buddhist thinkers, ${ }^{35}$ and Hindu thinkers, ${ }^{36}$ as well among non-religious thinkers. In the end we will need a plurality of arguments, which while they will not agree on basic concepts and presuppositions, will converge on the same basic point. We need a new ethic, a new religion of the earth, in the subjective genitive sense, not a religion that takes the earth as its object of worship, but a religion that is of the earth, and remains faithful to the earthly origin of all religions, cultures, economies, philosophies, and scientific advances. Every religion will have to find its earthly orientation in its own cult and creed, and will need to combat those interpretations which are not conducive to reverence for nature, for all religions are in one text or another guilty of hatred of the earth. Only a new religion of the earth can ground the new universalism which we are all reaching for. This will not be the universalism of St. Paul, or the Buddha, or the Prophet Mohammed, nor the modern universalisms of liberalism and Marxism. While it might take its point of departure from these historical forms of universalism, this will be a universalism which will be adapted to the new conditions of Anthropocenic existence. We need to tell a new story about ourselves, one that can bring us all together in an engaged and sober futurism. We are not only the people of the end-times, we are also the primitives of a new civilization.

32. This argument has been well made by Paul Gilding in The Great Disruption: Why the Climate Crisis Will Bring On the End of Shopping and the Birth of a New World (London: Bloomsbury, 2011).

33. Timothy Morton, The Ecological Thought (Cambridge, MA: Harvard University Press, 2010).

34. LSE "What Does Islam Have to Say About the Environment?" [Interview with Tim Winter], YouTube video, 6:53, January 23, 2020, https://www.youtube.com/watch?v=ZmvmWCLNj3w.

35. Thich Nhat Hahn, "Thich Nhat Hanh's Statement on Climate Change for the United Nations," September 2015, https://plumvillage.org/about/thich-nhat-hanh/letters/thich-nhat-hanhs-statement-on-climate-change-for-unfccc/

36. "Hindu Declaration on Climate Change," November 23, 2015, http://fore.yale.edu/climate-change/statements-fromworld-religions/hinduism/. 


\section{Bibliography}

Benz, Ernst. Evolution and Christian Hope: Man's Concept of the Future: From the Early Father to Teilhard de Chardin. Trans. Heinz G. Frank. Garden City: Anchor Books, 1965.

Brabazon, James. Albert Schweitzer: A Biography. Second Edition. Syracuse: Syracuse University Press, 2000.

Campbell, Colin. The Romantic Ethic and The Spirit of Modern Consumerism. Oxford: Blackwell, Campbell, 1987.

Cassirer, Ernst. An Essay on Man: An Introduction to the Philosophy of Human Culture. New Haven: Yale University Press, 1944.

Chesterton, G.K. "Child of the Snows." 1926. https://www.chesterton.org/a-child-of-the-snows/.

Dickens, Charles. A Christmas Carol. London: Chapman \& Hall, 1843.

Francis I. Encyclical Letter Laudato Si': On Care for Our Common Home. May 24, 2015. Vatican Website. http://www.vatican.va/content/francesco/en/encyclicals/documents/papa-francesco _2015 20150524_enciclica-laudato-si.html.

Gauchet, Marcel. The Disenchantment of the World: A Political History of Religion. Translated by Oscar Burge. Princeton: Princeton University Press, 1999.

Gilding, Paul. The Great Disruption: Why the Climate Crisis Will Bring on the End of Shopping and the Birth of a New World. London: Bloomsbury: 2011.

Gillespie, Michael Allen. The Theological Origins of Modernity. Chicago: University of Chicago Press, 2009.

Goodin, David. An Agnostic in the Fellowship of Christ: The Ethical Mysticism of Albert Schweitzer. Lanham, MD: Fortress Academic, 2019.

- The New Rationalism: Albert Schweitzer's Philosophy of Reverence for Life. Montreal \& Kingston: McGill-Queen's University Press, 2013.

—. "Schweitzer Reconsidered: The Applicability of Reverence for Life as Environmental Philosophy." Environmental Ethics 29, no. 4 (Winter 2007): 403-421.

Hahn, Thich Nhat. "Statement on Climate Change for the United Nations." September 2015. https://plumvillage.org/about/thich-nhat-hanh/letters/thich-nhat-hanhs-statement-on-climatechange-for-unfccc/.

Heidegger, Martin. "Memorial Address.” In Discourse on Thinking. Translated by John M. Anderson and E. Hans Freund. New York: Harper and Row, 1966.

“Hindu Declaration on Climate Change.” November 23, 2015. http://fore.yale.edu/climate-change/ statements-from-world-religions/hinduism/. 
Holmgren David, and Bill Mollison. Permaculture One: A Perennial Agricultural System for Human Settlements. London: Transworld Publishers, 1978.

Langer, Susanne K. Philosophy in a New Key: A Study in the Symbolism of Reason, Rite, and Art. Third Edition. Cambridge, MA: Harvard University Press, 1957.

Latour, Bruno. Facing Gaia: Eight Lectures on the New Climatic Regime. Translated by Cathy Porter. Cambridge: Polity Press, 2017.

Lonergan, Bernard. Method in Theology. Toronto: University of Toronto Press, 1971.

Merton, Thomas. New Seeds of Contemplation. New York: New Directions, 1961.

Moltmann, Jürgen. The Trinity and the Kingdom. Translated by Margaret Kohl. Minneapolis: Fortress Press, 1980.

Morton, Timothy. The Ecological Thought. Cambridge, MA: Harvard University Press, 2010.

Ricoeur, Paul. Freud and Philosophy: An Essay on Interpretation. Translated by Denis Savage. New Haven: Yale University Press, 1970.

Schelling, F.W.J. Philosophical Investigations into the Essence of Human Freedom. Translated by Jeff Love and Johannes Schmidt. Albany: State University of New York Press, 2006.

Schweitzer, Albert. Out of My Life and Thought: An Autobiography. Baltimore, MD: John Hopkins University Press, 2009.

Scruton, Roger. How to Think Seriously About Saving the Planet: The Case for an Environmental Conservatism. Oxford: Oxford University Press, 2012.

Seidler, Victor. Kant, Respect, and Injustice: The Limits of Liberal Moral Theory. Abington: Routledge, 1986.

Tillich, Paul. Systematic Theology. Three volumes in one. Chicago: University of Chicago Press 1967.

- The Essential Tillich: An Anthology of the Writings of Paul Tillich. Edited by F. Forrester Church. Chicago: University of Chicago Press. 1999.

Weber, Bob. “Oil sands can’t be burned.” CTV News, January 7, 2015. https://www.ctvnews.ca/ canada/85-of-oilsands-can-t-be-burned-if-world-to-limit-global-warming-report-1.2177568.

Weber, Max. "Wissenschaft als Beruf." In Gesammlte Aufsaetze zur Wissenschaftslehre, 524-55. Tübingen, 1922.

White Jr., Lynn. “The Historical Roots of our Ecological Crisis.” Science 155 (1967): 1203-1207.

Williams, Mark, Jan Zalasiewicz, P. K. Haff, Christian Schwägerl, Anthony D. Barnosky and Erle C. Eills. “The Anthropocene Biosphere.” Anthropocene Review 2, no. 3 (2015): 196-219. 
LSE. "What Does Islam Have to Say About the Environment?" [Interview with Tim Winter]. YouTube Video, 6:53, January 23, 2020. https://www.youtube.com/watch?v=ZmvmWCLNj3w.

Žižek, Slavoj. The Indivisible Remainder. On Schelling and Related Matters. London: Verso, 1996. 